\title{
Phytotoxicity and cytotoxicity of Lepidaploa rufogrisea (Asteraceae) extracts in the plant model Lactuca sativa (Asteraceae)
}

\author{
Francielen Barroso Aragão ${ }^{1}$, Vagner Tebaldi Queiroz ${ }^{2}$, Adésio Ferreira ${ }^{3}$, Adilson Vidal Costa ${ }^{2}$, \\ Patricia Fontes Pinheiro ${ }^{2}$, Tatiana Tavares Carrijo ${ }^{4} \&$ Larissa Fonseca Andrade-Vieira ${ }^{5 *}$ \\ 1. Department of Biological Sciences, Center of Human and Natural Sciences, Universidade Federal do Espírito Santo, \\ 29075-910 Vitória - ES, BR; francielenaragao@gmail.com \\ 2. Department of Chemistry and Physics, Center of Agronomical Sciences, Universidade Federal do Espírito Santo, \\ 29500-000 Alegre-ES, BR; vagnertq@gmail.com, avcosta@hotmail.com, patriciafontespinheiro@hotmail.com \\ 3. Department of Plant Production, Center of Agricultural Sciences, Universidade Federal do Espírito Santo, 29500-000 \\ Alegre-ES, BR; adesioferreira@gmail.com \\ 4. Department of Biology, Center of Agronomical Sciences, Universidade Federal do Espírito Santo, 29500-000 Alegre \\ -ES, BR; tcarrijo@gmail.com \\ 5. Department of Biology, Universidade Federal de Lavras, 37200-000 Lavras - MG, BR; 1fandrade.vieira@gmail.com \\ * Correspondence
}

Received 22-VII-2016. C Corrected 06-II-2017. Accepted 02-III-2017.

\begin{abstract}
Lepidaploa rufogrisea is a promising candidate in the search of natural herbicides, with compounds (sesquiterpene lactones-glaucolide B) which have been reported to present phytotoxic potential against weeds. Thus, this work aimed to accomplish the phytochemical investigation of $L$. rufogrisea as well as the evaluation of its biological effects on the plant model Lactuca sativa. To this end, different extracts (aqueous, hydroalcoholic and hexane) of $L$. rufogrisea at different concentrations $[0.25,0.5,1.0,2.0$ and $4.0 \%(\mathrm{~m} / \mathrm{v})]$ were evaluated from macroscopic (percentage of germinated seeds, germination speed index and root length) and microscopic analysis (mitotic index and cell cycle alterations) in plantlets (150 per treatment) and meristematic cells (10000 per treatment) of $L$. sativa var. Cristina. The extracts decreased the germination speed index and also the root growth of L. sativa plantlets. Cell proliferation was not significantly affected by the extracts. However, some chromosome and nuclear alterations in the mitotic spindle were observed, due to the interference of allelochemicals present in L. rufogrisea. Moreover, the plant model L. sativa demonstrated to be efficient for this kind of studies. Rev. Biol. Trop. 65 (2): 435-443. Epub 2017 June 01.
\end{abstract}

Key words: cytotoxicity, phytotoxicity, root growth, allelopathic potential, cell cycle alterations, plant bioassays.

The continuous use of pesticides may bring negative effects to human health and the environment (Souza Filho, Lobo, \& Arruda, 2005). Besides environmental pollution, synthetic herbicides, could increase the incidence of weeds (Narwal, 1999). Thus, there is an incentive to seek alternative strategies for weeds control and management. To achieve this goal, systems of sustainable agriculture have been developed. It is based on plants or plant-derived products that are used as bioherbicides, less hazardous to the environment, to the control of pests, diseases and invading plants in crops (Isman, 2006; Kato-Noguchi, Takeshita, Kimura, Ohno, \& Suenaga, 2013).

Lepidaploa rufogrisea (A. St.-Hil.) H. Rob. (family Asteraceae) has stood out in previous studies for its allelopathic potential, due to the sesquiterpene lactones (glaucolide B) (Padolina et al., 1974), which showed phytotoxic activity against various weeds (Macias, Varela, Torres, Oliva, \& Molinillo, 1998; Wedge, Galindo, \& Macias, 2000). The allelopathic activity of a plant-derived product is of research interest 
as they are sources of bioactive chemicals for bioherbicides formulation.

In this context, seed germination and plantlet growth, parameters accessed by macroscopic analysis using a model plant species, are the bioassays most commonly used for study and identification of the allelopathic potential of allelochemicals extracted or present in plants (Rice, 1984). Although these assays provide general information about the biological effects of such allelochemicals, they do not inform about their mechanisms of action in the target plant (Campos, Davide, Soares, \& Viccini, 2008). Therefore, the evaluation of microscopic parameters via cytogenetic assay is a strategy that has been developed in addition to macroscopic analyses (Andrade, Davide, \& Gedraite, 2010). Cytogenetic assays are based on the evaluation of the cell cycle, allowing the observation of alterations throughout the mitosis. It also enables to identify whether the extract in question presents cytotoxic, genotoxic, mutagenic or even carcinogenic action (Leme \& Marin-Morales, 2009).

Among the plant models used for allelopathic studies, the species Lactuca sativa L. can be highlighted (Campos et al., 2008). Besides being highly sensitive and enabling the simultaneous analysis of various compounds (Grant, 1994), it also exhibits high proliferation rate, rapid germination (up to $24 \mathrm{~h}$ ), and has been useful in the analysis of cytogenetic parameters (Andrade et al., 2010; Andrade-Vieira, Botelho, Palmieri, Laviola, \& Praça-Fontes, 2014). Moreover, the laboratory procedures for these tests generally have low operational costs and generate results within a short time. Considering all the above, the present work aimed to investigate the mechanisms of action of different extracts (aqueous, hydroalcoholic and hexane) of L. rufogrisea on the germination, plantlet development and meristematic root tip cells of $L$. sativa.

\section{MATERIALS AND METHODS}

Chemical products: Hexane, ethanol and acetic acid were purchased from Vetec Química
Fina Ltda. (Duque de Caxias, Rio de Janeiro, Brazil). Tween ${ }^{\circledR} 80$ and acetone were purchased from Isofar Indústria e Comércio de Produtos Químicos Ltda. (Duque de Caxias, Rio de Janeiro, Brazil). The other chemicals used in this study were purchased from Sigma-Aldrich (Minas Gerais, Brazil).

Materials: The collection of L. rufogrisea samples was carried out in October 2011 at the Natural Reserve of Vale do Rio Doce, Linhares (ES, Brazil), in Mussununga-type vegetation. The plant material in the field was flowering. A young branch, with a flower, was collected, dried, and the exsiccate (T.T. Carrijo n. 1406) was mounted and deposited in the herbarium of Federal University of Espírito Santo VIES, section of Jerônimo Monteiro (voucher no. 537), with duplicates in the herbarium of the Natural Reserve of Vale (CVRD).

Seeds of L. sativa $\mathrm{L} .(2 \mathrm{n}=2 \mathrm{x}=18)$ var. "Cristina" (Feltrin Seeds), purchased at agribusiness shops, were used as test system to evaluate the phytotoxicity and cytogenotoxic potential of the different extracts obtained from L. rufogrisea.

Phytochemical investigation: The aerial parts (young stem and leaves) of L. rufogrisea were dried in forced air circulation dehydrator (S480AD, Biopar, Porto Alegre- RS, Brazil) for a period of seven days at $40{ }^{\circ} \mathrm{C}$, then broken into smaller pieces and pulverized in cutting mill (MA-340, Marconi, Piracicaba - SP, Brazil). The obtained powder was stored in tightly closed vessel protected from light incidence. The powder was used to prepare the aqueous, hydroalcoholic and hexane extracts at $10 \%$ $(\mathrm{m} / \mathrm{v})$, and phytochemical screening was performed. The phytochemical analyses to determine the main chemical classes of secondary metabolites (alkaloids, phenolic compounds, terpenoids and steroids) were performed according to protocol described by Matos (2009).

Preparation of extracts: The aqueous, hydroalcoholic and hexane extracts were obtained by cold maceration of the L. rufogrisea 
powder (200 g) for $120 \mathrm{~h}$ at room temperature, using distilled water, $70 \%$ ethanol (v/v) and hexane, respectively. At the end of the extraction, each mixture was centrifuged (6 000 RPM, 20 min at $25^{\circ} \mathrm{C}$ ) and the supernatants were vacuum filtered.

The aqueous extract was transferred to volumetric flask ( $2 \mathrm{~L}$ ) with the volume being adjusted with distilled water. The hydroalcoholic and hexane extracts were transferred to forced air circulation dehydrator (S480AD, Biopar, Porto Alegre - RS, Brazil) at $50{ }^{\circ} \mathrm{C}$, where they were maintained until complete evaporation of the solvent. The dry material obtained from the hydroalcoholic extract was dissolved in distilled water. For the hexane extract, dissolution was performed using aqueous solution of $1.0 \%$ Tween $^{\circledR} 80(\mathrm{v} / \mathrm{v})$ and $0.5 \%$ acetone (v/v) (ISOFAR, Duque de Caxias - RJ, Brazil).

For investigation of phytotoxicity and cytotoxic potential, the obtained aqueous, hydroalcoholic and hexane extracts were used to prepare the test solutions at the concentrations of $0.25 \%, 0.5 \%, 1.0 \%, 2.0 \%$ and $4.0 \%(\mathrm{~m} / \mathrm{v})$. Distilled water was used as negative control for aqueous and hydroalcoholic extracts. For hexane extract the negative control applied were an aqueous solution of $1.0 \%$ Tween ${ }^{\circledR} 80(\mathrm{v} / \mathrm{v})$ with $0.5 \%$ acetone $(\mathrm{v} / \mathrm{v})$.

Macroscopic analysis: The seeds of $L$. sativa were disposed into a Petri dishe that was treated with $15 \mathrm{~mL}$ of the test solutions as described on Aragão et al. (2015). The experimental design was completely randomized (RGD), with five dishes for each treatment, each containing 50 seeds of $L$. sativa. The germination conditions followed Aragão et al. (2015).

The germination rate (GR), the germination speed index (GSI) and root growth rate (RG) were recorded and calculated according to Aragão et al. (2015).

Microscopic analysis: To evaluate the action mechanism of L. rufogrisea extracts, analyses of cell cycle were performed in meristematic cells of $L$. sativa, after their exposure in test solutions for $48 \mathrm{~h}$. Roots were collected, fixed and the slides were prepared (two slides per Petri dish) and evaluated as described Aragão et al. (2015). Ten slides were accessed for each treatment and about 10000 meristematic cells were counted per treatment. The mitotic index (MI), frequency of chromosomal (CA) and nuclear (NA) alterations were recorded as described Aragão et al. (2015).

The parameters evaluated in the study (GR, GSI, RG, MI, CA and NA) were subjected to analysis of variance (ANOVA). The mean values obtained were compared by Dunnett's test at $5 \%$ significance level.

\section{RESULTS}

The classes of secondary metabolites present in the L. rufogrisea extracts were phenolic compounds and terpenoids/steroids (Table 1). In the class of phenolic compounds, presence of metabolites anthraquinones, coumarins, tannins, xanthones and flavonoids (catechins, flavonols and flavanones) was verified. For terpenoids/steroids some saponins, alpha-beta unsaturated lactones, steroidal nucleus and 2-deoxy sugars were identified.

Figure $1 \mathrm{~A} 1$, figure $1 \mathrm{~B} 1$ and figure $1 \mathrm{C} 1$ presents the general aspect of the plantlets exposed for $48 \mathrm{~h}$ to L. rufogrisea extracts. It was observed that the aqueous, hydroalcoholic and hexane extracts did not interfere with the final germination of $L$. sativa seeds (GR) (Fig. 1 A2, Fig. 1B2, Fig. 1C2). For the parameters GSI and RG, the phytotoxic effect became more evident with increasing concentration of the extracts (Fig. 1 A3, Fig. 1 A4, Fig. 1 B3, Fig. 1 B4, Fig. 1 C3 y Fig. 1 C4).

For the aqueous extract, GSI did not present statistical difference between any of the tested concentrations and the (-) control (Fig. 1 A3). As for RG, a decrease was observed in the size of the roots, being significant from the concentration of $0.5 \%$ compared to the (-) control (Dunnett, $\mathrm{P}<0.05$ ) (Fig. 1 A4). This growth inhibition reached $44.75 \%$ for the highest tested concentration $(4.0 \%)$. With the hydroalcoholic extract (Fig. 1 B1, Fig. 1 B2, 
TABLE 1

Classes of secondary metabolites present in the aerial parts of L. rufogrisea

\begin{tabular}{llll}
\multicolumn{1}{c}{ Chemical class } & & \multicolumn{2}{c}{ Chemical class } \\
Alkaloids & - & Flavonoids & - \\
Phenolic compounds & & Chalcones & + \\
Anthraquinones & + & Flavonols & + \\
Coumarins & + & Flavanones & \\
Tannins & + & Terpenoids and steroids & + \\
Xanthones & + & Saponins & + \\
Flavonoids & & Alpha, beta-unsaturated lactones & + \\
\multicolumn{1}{c}{ Aurones $\quad$ Catechins - Catechin tannins } & - & Steroid nuclei & + \\
\hline
\end{tabular}

The signs (+) and (-) indicate, respectively, the presence or absence of the chemical classes in the analyzed plant material.
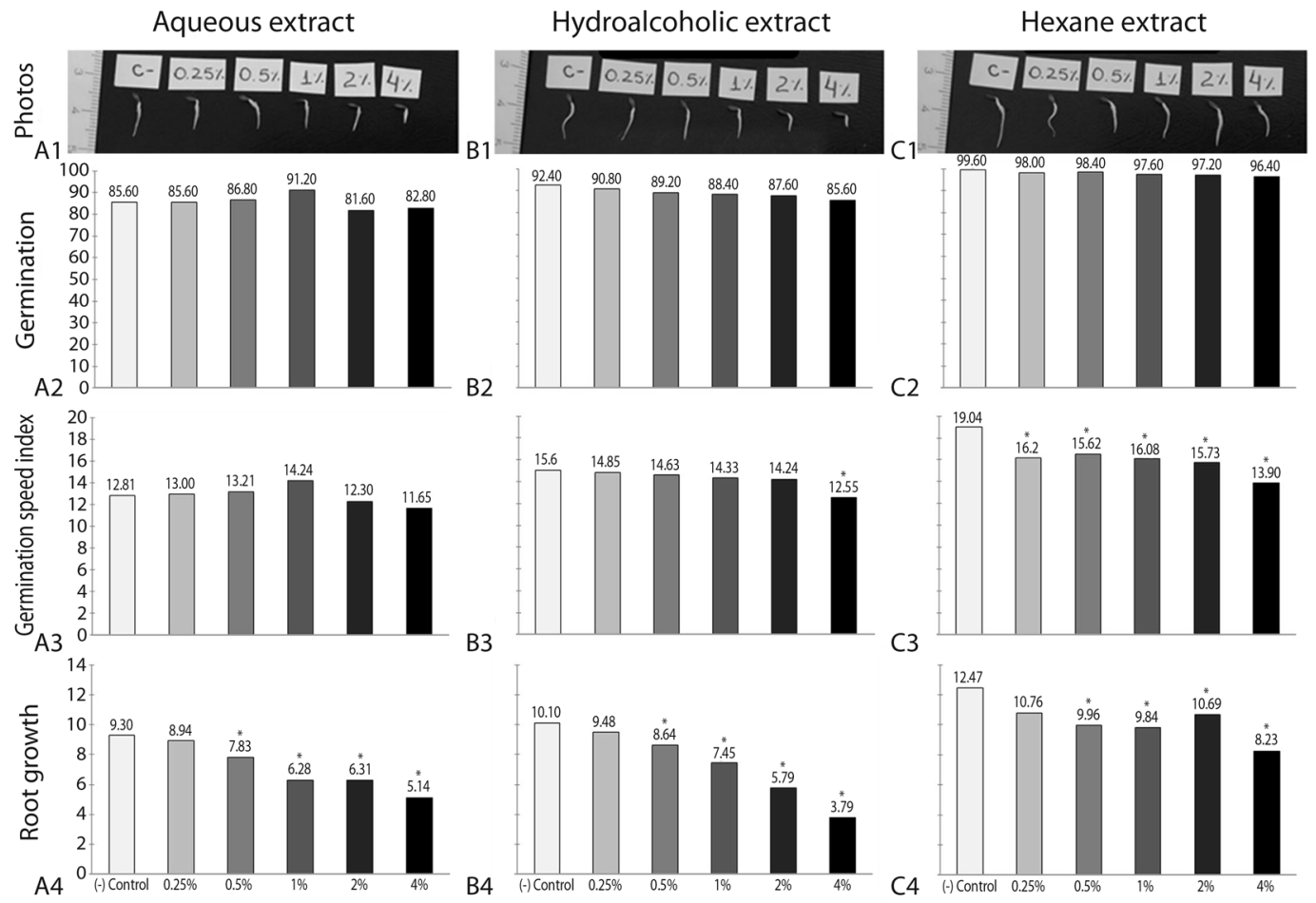

Fig. 1. Macroscopic parameters accessed on L. sativa after treatment with different concentrations of L. rufogrisea extracts. Bars followed by $(*)$ are significantly different from the control $(\mathrm{p}<0.05)$ according to Dunnett's test. The $(-)$ control applied for aqueous and hydroalcoholic extracts was distilled water and for hexane extract was the solution of $1.0 \%$ Tween ${ }^{\circledR} 80$ $(\mathrm{v} / \mathrm{v})$ with $0.5 \%$ acetone $(\mathrm{v} / \mathrm{v})$ due to the low solubility of this extract in water.

Fig.1 B3, Fig. 1 B4), difference was observed for GSI (Fig. 1 B3) in the treatment at $4.0 \%$, with reduction of $16.68 \%$ compared to the control (Dunnett, $\mathrm{P}<0.05$ ). A statistical difference was detected in RG (Fig. 1 B4) starting at the extract concentration of $0.5 \%$, showing a reduction of $14.44 \%$, to $62.47 \%$ in relation to the control (Dunnett, $\mathrm{P}<0.05$ ). The means for hexane extract (Fig. $1 \mathrm{C} 1$, Fig. $1 \mathrm{C} 2$, Fig. $1 \mathrm{C} 3$ y Fig. $1 \mathrm{C} 4)$ concentrations demonstrated 
a significant reduction in GSI (Fig. $1 \mathrm{C} 3$ ) in all treatments (Dunnett, $\mathrm{P}<0.05$ ). At the highest concentration, the observed germination rate was approximately 13.90 seedlings / day, which shows a delay in germination of $26.99 \%$ in this case. The RG (Fig. $1 \mathrm{C} 4$ ) indicated decrease in root size for all concentrations of hexane extract, being significant from $0.5 \%$ compared to the negative control (distilled water). This growth inhibition reached as much as $40.13 \%$ for the highest tested concentration (4.0\%).

No statistical difference was verified in mitotic index (MI) for the aqueous and hexane extracts (Dunnett, $\mathrm{P}<0.05$ ) (Table 2). However, a significant decrease in MI was observed for the hydroalcoholic extract at the concentration of $4.0 \%$ (Table 2). This reduction was of approximately $17 \%$ in relation to the control, and is hence related to the decrease in root growth caused by the latter extract (Fig. 1).

The aqueous extract presented statistical difference for metaphases at the concentration of $0.25 \%$ (Dunnett, $\mathrm{P}<0.05$ ) (Table 2). For the hydroalcoholic extract a decrease was observed in the percentage of prophases at the concentration of $1.0 \%$, and a significant increase in metaphases at the concentration of $4.0 \%$ (Dunnett, $\mathrm{P}<0.05$ ) (Table 2). With the hexane extract, a significant increase in metaphases occurred from $0.5 \%$ up to the highest concentration $(4.0 \%)$, in which the increase was 1.4-fold in relation to the negative control (Table 2).

With regards to total cell cycle alterations, it was observed that, with increasing concentration of the extracts, an increase occurred

TABLE 2

Microscopic parameter accessed in meristematic cells of roots tips from L. sativa after exposure to different concentrations of $L$. rufogrisea extracts

\begin{tabular}{|c|c|c|c|c|c|c|c|}
\hline \multirow{2}{*}{$\begin{array}{l}\text { Applied concentration } \\
\qquad(\mathrm{m} / \mathrm{v})\end{array}$} & \multirow{2}{*}{$\begin{array}{l}\text { Mitotic } \\
\text { index }\end{array}$} & \multicolumn{4}{|c|}{ Mitotic phase (\%) } & \multirow{2}{*}{$\begin{array}{c}\text { Total of cell cycle } \\
\text { alterations }(\%)\end{array}$} & \multirow{2}{*}{$\begin{array}{c}\text { Nuclear alterations } \\
(\%)\end{array}$} \\
\hline & & PRO & MET & ANA & TEL & & \\
\hline \multicolumn{8}{|c|}{ Aqueous Extract } \\
\hline (-) control & 9.2 & 57.45 & 19.77 & 9.4 & 24.66 & 0.27 & 0.08 \\
\hline $0.25 \%$ & 9.03 & 49.8 & $26.79 *$ & 11.05 & 16.57 & 0.7 & 0.34 \\
\hline $0.5 \%$ & 8.48 & 52.37 & 24.85 & 7.34 & 18.49 & $0.97 *$ & 0.29 \\
\hline $1 \%$ & 8.95 & 53.13 & 23.52 & 10.44 & 16.85 & $0.79 *$ & 0.29 \\
\hline $2 \%$ & 8.67 & 51.28 & 22.66 & 11.83 & 18.08 & $1.75 *$ & $0.46 *$ \\
\hline $4 \%$ & 9.4 & 55.41 & 24.58 & 8.87 & 14.79 & $2.08 *$ & $0.65 *$ \\
\hline \multicolumn{8}{|c|}{ Hydroalcoholic extracts } \\
\hline (-) control & 15.06 & 54.38 & 23.41 & 13.83 & 11.78 & 0.13 & 0 \\
\hline $0.25 \%$ & 14.85 & 44.47 & 25.02 & 19.14 & 15.2 & $0.72 *$ & $0.45^{*}$ \\
\hline $0.5 \%$ & 14.63 & 45.08 & 29.1 & 17.03 & 13.01 & $1.08^{*}$ & $0.60 *$ \\
\hline $1 \%$ & 14.33 & $43.98^{*}$ & 29.33 & 19.06 & 10.14 & $1.24 *$ & $0.46^{*}$ \\
\hline $2 \%$ & 14.24 & 47.86 & 29.8 & 15.18 & 9.04 & $1.15^{*}$ & $0.67 *$ \\
\hline $4 \%$ & $12.55^{*}$ & 47.32 & $32.08 *$ & 13.07 & 6.03 & $0.95 *$ & $0.99 *$ \\
\hline \multicolumn{8}{|c|}{ Hexane extract } \\
\hline (-) control & 8.16 & 53.56 & 22.53 & 16.75 & 8.49 & 0.19 & 0.06 \\
\hline $0.25 \%$ & 8.66 & 47.78 & 28.6 & 14.96 & 10.55 & $0.51 *$ & 0.15 \\
\hline $0.5 \%$ & 7.61 & 41.33 & $34.86^{*}$ & 15.32 & 10.41 & $0.75 *$ & 0.18 \\
\hline $1 \%$ & 7.67 & 46.69 & $33.42 *$ & 12.38 & 7.94 & $0.98 *$ & $0.37 *$ \\
\hline $2 \%$ & 7.59 & 41.49 & $32.49 *$ & 14.76 & 11.92 & $0.91 *$ & $0.30 *$ \\
\hline $4 \%$ & 8.3 & 41.45 & $34.53 *$ & 15.49 & 9.18 & $1.29 *$ & $0.36^{*}$ \\
\hline
\end{tabular}

The means followed by $\left(^{*}\right)$ are significantly different from the control $(\mathrm{P}<0.05)$ according to Dunnett's test. The $(-)$ control applied for aqueous and hydroalcoholic extracts was distilled water and for hexane extract was the solution of $1.0 \%$ Tween ${ }^{\circledR}$ $80(\mathrm{v} / \mathrm{v})$ with $0.5 \%$ acetone $(\mathrm{v} / \mathrm{v})$ due to the low solubility of this extract in water. PRO = prophase; MET = metaphase; ANA $=$ anaphase $;$ TEL $=$ telophase. 
in the damage of meristematic cells of the evaluated roots (Table 2).

Overall, for the distinct tested extracts a significant difference was observed starting at the concentration of $0.25 \%$ (Dunnett, $\mathrm{P}<0.05$ ) (Table 2). At the concentration of 4.0 $\%$, the aqueous, hydroalcoholic and hexane extracts presented chromosome alteration percentages 10.37, 7.3 and 11.98 times as high as the control, respectively. The most frequent chromosome aberrations were observed during metaphase, highlighting the occurrence of sticky chromosomes (Fig. 2D), C-metaphases (Fig. 2E) and polyploid C-metaphases (Fig. 2F). Such fact explains the significant difference between metaphases for all extracts (Table 2).

Evaluation of the nuclear alterations revealed a difference starting at the concentration of $0.25 \%$ for the hydroalcoholic extract, from $1.0 \%$ for the hexane extract and from $2.0 \%$ for the aqueous extract (Table 2). In Table 2, it can be observed that the significant
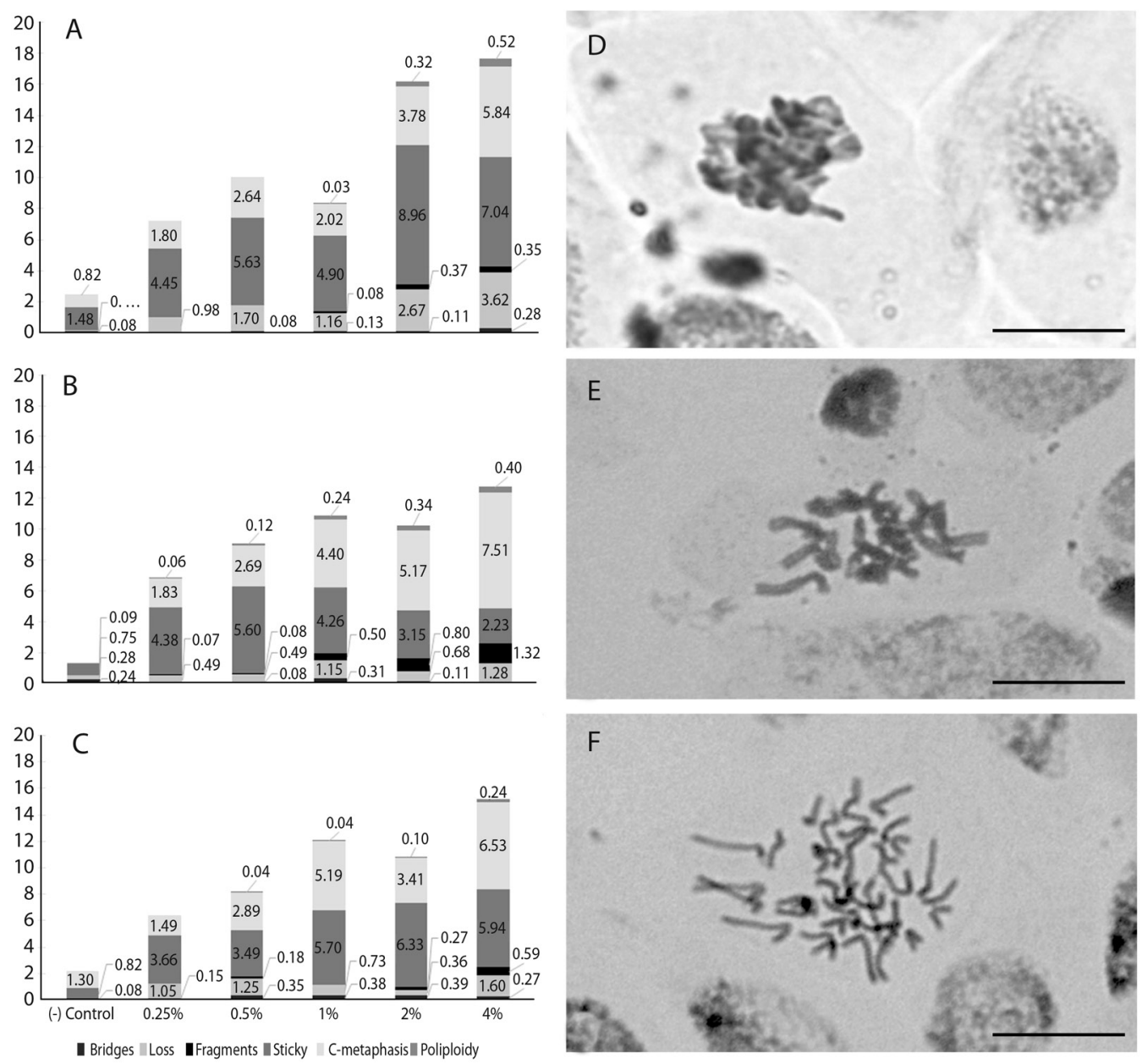

Fig. 2. Chromosomal alterations in meristematic cells of roots tips from L. sativa after exposure to different concentrations of L. rufogrisea extracts The (-) control applied for aqueous (A) and hydroalcoholic (B) extracts was distilled water and for hexane (C) extract was the solution of $1.0 \% \operatorname{Tween}^{\circledR} 80(\mathrm{v} / \mathrm{v})$ with $0.5 \%$ acetone $(\mathrm{v} / \mathrm{v})$ due to the low solubility of this extract in water. (D-F) The main observed chromosomal alterations observed: (D) sticky chromosomes/metaphases. (E) $\mathrm{C}$-metaphases and (F) polyploid C-metaphases. The images were obtained on light microscope at oil objective with total magnification of $1000 \mathrm{x}$. Bar $=10 \mu \mathrm{m}$. 
increase for the hexane extract started at the concentration of $1.0 \%$ (Dunnett, $\mathrm{P}<0.05$ ). The most evident nuclear alteration was the condensed nucleus.

\section{DISCUSSION}

The present work demonstrated the mechanism of action of L. rufogrisea extracts through macroscopic and microscopic analyses. The extracts showed phytotoxicity by reducing root growth in the initial development of L. sativa plantlet. This evidenced the action of the allelochemicals present in the different extracts of L. rufogrisea tested in the study.

Phenolic compounds, present in the extracts are highly chemically reactive compounds, and comprise the water-soluble allelochemicals most common in plants showing allelopathic potential. Studies indicated that the phenolic compounds may influence the absorption of nutrients by the roots, consequently reducing the growth of weeds ( $\mathrm{Li}$, Wang, Ruan, Pan, \& Jiang, 2010). They also alter the permeability of the plasma membrane, the protein synthesis, enzyme activity, hormone synthesis and the photosynthetic process, consequently affecting the normal plant growth (Li et al., 2010). This way, the effect observed with the inhibition of root growth by the aqueous and alcoholic extracts of L. rufogrisea, may be associated to the presence of phenolic compounds in these extracts.

Triterpenes and steroids, also present in the extracts, are responsible for the toxicity of plant extracts, with their mechanism of action most likely involving rupture of the cell membrane by lipophilic compounds (Almeida, Miotto, Nunes, Spadari-Bratifisch, \& Brito, 2002). Saponins reduce the superficial water tension, and its detergent and emulsifying activities are capable of disorganizing cell membranes (Spargh, Light, \& Van Staden, 2004). Alpha-beta unsaturated lactones are known as sesquiterpene lactones, and have been denoted for their allelopathic potential by inducing significant reduction in germination and growth of roots and aerial part, especially in dicots such as Arabidopsis thaliana, L. sativa, Lepidium sativum and Lycopersicon esculentum (Macias, Torres, Molinllo, Varela, \& Castellano, 1996; Chadwick, Trewin, Gawthrop, \& Wagstaff, 2013; Hussain \& Reigosa, 2014).

According to Harashima and Schnittger (2010), cell division and growth of the plant body are closely related, and where growth depends upon cell proliferation. Then, the alterations in the cell cycle observed reflect directly on macroscopic parameters (GR, GSI and RG). Initially, the decline in MI is a function of the division blockade as well as of death of the nucleus, hindering the beginning of the prophase and hence the cell division (Sousa, Silva, Campos, \& Viccini, 2009), which explains the reduction in root growth (Andrade et al., 2010).

Despite this relationship, the evaluated microscopic parameters (MI, CA and NA) were not sufficient to explain the effects of the extracts on the macroscopic parameters, especially the root growth rate, since there was no significant reduction in cell division rate. However, another factor that affects the growth of organs such as the root is the cell elongation during the development and differentiation process (Harashima \& Schnittger, 2010).

The cell differentiation depends, among others, on the activity of enzymes responsible for the cell expansion process, remodeling of the cell wall and deposition of cellulose, combined to events of turgor pressure via water absorption (Taiz \& Zeiger, 2013). The presented data make evident that the allelochemicals found in the extracts act negatively on the cell machinery responsible for cell elongation. In this context, both the phenolic compounds as well as the sesquiterpene lactones may directly influence the process of cell differentiation, since these metabolite classes have the capacity of inactivating the synthesis of proteins and the activity of enzymes (Bachelier, Mayero, \& Kleina, 2006; Li et al., 2010).

For instance, Li, Inoue, Nishimura, Mizutani and Tsuzuki (1993) verified that coumarin, present on L. rufogrisea extracts significantly inhibits the elongation of lettuce roots, thus increasing the thickness of the cortex cells 
and reducing the cellular activity. In addition, phenolic allelochemicals have the capacity of altering the integrity of the DNA and RNA (Zeng, Luo, \& Shi, 2001). Among the mechanisms proposed to sesquiterpene lactones action, for example, is the ability of the lactone molecule to react with nucleophiles present in the DNA molecules or sulfur atoms from amino acids of proteins/enzymes, unleashing an oxidative process (Bachelier et al., 2006). Oxidative stress is a process closely related to cell death, which is evidenced, cytologically, as a condensed nucleus (Vermes, Haanem, \& Reutelingsperger, 2000), that was observed in treated cells of this work.

The induction of alterations on DNA and protein structure by L. rufogrisea allelochemicals are also in agreement with the action mechanism observed on microscopic analyses performed as the extracts induced chromosome alterations. In general, chromosome bridges and fragments indicated a clastogenic mechanism of action of the tested substance, with some activity related to genotoxicity (action on DNA structure). Differently, lost and sticky chromosomes and C-metaphases were related to an aneugenic mechanism of action, arising from a cytotoxic effect of the tested substance on proteins (Leme \& Marin-Morales, 2009; Andrade-Vieira, 2012). In this case, the extracts of $L$. rufogrisea presented mixed mode of action (aneugenic and clastogenic), since all types of alterations were observed to some extent after exposure of the meristematic cells to the extracts.

In conclusion, the work carried out here demonstrated the allelopathic effect of L. rufogrisea extracts through reduction of the root growth and germination speed index. The plant model $L$. sativa revealed to be efficient for the execution of the present study. There was no interference in the mitotic index; nevertheless, the chromosome alterations detected evidenced the aneugenic and clastogenic potential of the extracts. The mechanism of action of the allelochemicals corresponded to the inhibition of proteins related to cell growth and differentiation.

\section{ACKNOWLEDGMENT}

The authors is grateful to Universidade Federal do Espírito Santo to the opportunity to development this research.

\section{RESUMEN}

Fitotoxicidad y citotoxicidad de los extractos de Lepidaploa rufogrisea (Asteraceae) en la planta modelo Lactuca sativa (Asteraceae). Lepidaploa rufogrisea es una candidata prometedora en la búsqueda de herbicidas naturales, con compuestos (lactano sesquiterpeno- glaucolíde B) los cuales han sido reportados por presentar un potencial fitotóxico contra las malas hierbas. Por lo tanto, este trabajo tuvo como objetivo lograr la investigación fitoquímica de L. rufogrisea, así como también la evaluación de sus efectos biológicos sobre el modelo de planta Lactuca sativa L. Para esto, diferentes extractos (acuosos, hidroalcohólicos y hexanos) de L. rufogrisea fueron evaluados. El porcentaje de semillas germinadas, el índice de velocidad de germinación y la longitud de raíz de plántulas de $L$. sativa var. Cristina fueron evaluadas, así como también la citotoxicidad de los extractos en las células meristemáticas. Los extractos disminuyeron el índice de velocidad de germinación y también el crecimiento de las raíces de las plántulas de L. sativa. La proliferación celular no se vio significativamente afectada por los extractos. Sin embargo, se observaron alteraciones cromosómicas y nucleares, debido a la interferencia de los aleloquímicos presentes en L. rufogrisea en el huso mitótico. Además, el modelo de planta L. sativa demostró ser eficiente para tales estudios.

Palabras clave: citotoxicidad, fitotoxicidad; crecimiento radicular, potencial alelopático, alteraciones del ciclo celular, bioensayos de plantas.

\section{REFERENCES}

Almeida, A. B. A., Miotto, A. M., Nunes, D. S., SpadariBratifisch, R. C., \& Brito, A. R. M. (2002). Mechanism of antiulcerogenic activity of semi-synthetic crotonin obtained from Croton cajucara Benth. Revista Brasileira de Farmacoginosia, 12, 105-110.

Andrade, L. F., Davide, L. C., \& Gedraite, L. S. (2010). The effect of cyanide compounds, fluorides and inorganic oxides present in spent pot liner on germination and root tip cells of Lactuca sativa. Ecotoxicology and Environmental Safety, 73, 626-631.

Andrade-Vieira, L. F. (2012). In G. B. C. Cabral \& B. A. E. Botehlho (Eds.), Landfills: Waste Management, Regional Practices and Environmental Impact (pp. 319-330). New York, USA: Nova Science Publishers. 
Andrade-Vieira, L. F., Botelho, C. M., Palmieri, M. J., Laviola, B. G., \& Praça-Fontes, M. M. (2014). Effects of Jatropha curcas oil in Lactuca sativa root tip bioassays. Academia Brasileira de Ciências, 86(1), 373-382.

Aragão, F. B., Palmieri, M. J., Ferreira, A., Costa, A. V., Queiroz, V. T., Pinheiro, P. F., \& Andrade-Viera, L. F. (2015). Phytotoxic and cytotoxic effects of Eucalyptus essential oil on Lactuca sativa L. Allelopathy Journal, 35, 259-272.

Bachelier, A., Mayerb, R., \& Kleina, C. D. (2006). Sesquiternes lactones are potent and irreversible inhibitors of the antibacterial target enzyme MurA. Bioorganic \& Medicinal Chemistry Letters, 16, 5605-5609.

Campos, J. M. S., Davide, L. C., Soares, G. L. G., \& Viccini, L. F. (2008). Mutagenic effects due to allelopathic action of fern (Gleicheniaceae) extracts. Allelopathy Journal, 22(1), 143-152.

Chadwick, M., Trewin, H., Gawthrop, F., \& Wagstaff, C. (2013). Sesquiterpenoids Lactones: Benefits to Plants and People. Internation Journal of Molecular Sciences, 14(6),12780-12805.

Grant, W. F. (1994). The present status of higher plant bioassay for detection of environmental mutagens. Mutation Researche, 310(2), 175-185.

Harashima, H., \& Schnittger, A. (2010). The integration of cell division, growth and differentiation. Current Opinion in Plant Biology, 13, 66-74.

Hussain, M. I., \& Reigosa, M. J. (2014). Evaluation of herbicide potential of sesquiterpene lactone and flavonoid: impact on germination, seedling growth indices and root length in Arabidopsis thaliana. Journal of Botany, 46(3), 995-1000.

Isman, M. B. (2006). Plant essential oils for pest and disease management. Annual Review Entomology, $51,45-56$.

Kato-noguchi, H., Takeshita, S., Kimura, F., Ohno, O., \& Suenaga, K. (2013). A novel substance with allelopathic activity in Ginkgo biloba. Journal of Plant Physiology, 170, 1595-1599.

Leme, D. M., \& Marin-Morales, M. A. (2009). Allium cepa test in environmental monitoring: A review on its application. Mutation Research, 682, 71-81.

Li, H. H., Inoue, M., Nishimura, H., Mizutani, J., \& Tsuzuki, E. (1993). Interaction of trans-cinnamic acid, its related phenolic allelochemicals, and abscisic-acid in seedling growth and seed-germination of lettuce. Journal of Chemical Ecology, 19, 1775-1787.
Li, Z. H., Wang, Q., Ruan, X., Pan, C. D., \& Jiang, D. A. (2010). Phenolics and plant allelopathy. Molecules, $15,8933-8952$.

Macias, F. A., Torres, A., Molinllo, J. M. G., Varela, R. M., \& Castellano, D. (1996). Potential allelopathic sesquiterpene lactones from sunflower leaves. Phytochemistry, 43, 1205-1215.

Macias, F. A., Varela, R. M., Torres, A., Oliva, R. M., \& Molinillo, J. M. G. (1998). Bioactive norsesquiterpenes from Helianthus annuuswith potential allelopathic activity. Phytochemistry, 48, 631-636.

Matos, F. J. A. (2009). Introdução à Fitoquímica Experimental $\left(3^{\mathrm{a}}\right.$ ed.). Fortaleza: UFC.

Narwal, S. S. (1999). Allelopathy Update, Basic and Applied Aspects. Enfield, NH: Science Publisher.

Padolina, W. G., Yoshioka, H., Nakatani, N., Mabry, T. J., Monti, A. S., Davis, R. E., Cox, P. J., Sim, A. O., Watson, W. H., \& Beth, W. I. (1974). Glaucolide -A and -B, new germacrano- lide-type sesquiterpene lactones from Vernonia (Compositae). Tetrahedron, $30,1161-1170$.

Rice, E. L. (1984). Allelopathy (2 ed.). Orlando, USA: Academic Press.

Sousa, M. S., Silva, O. S, Campos, J. M. S., \& Viccini, L. F. (2009). Cytotoxic and genotoxic effects of two medicinal species of Verbenaceae. Caryologia, 62(4), 326-333.

Souza Filho, A. P. S., Lobo, L. T., \& Arruda, M. S. P. (2005). Atividade alelopática de Tachigali myrmecophyla. Planta Daninha, 23, 557-564.

Spargh, S. G., Light, M. E., \& Van Staden, J. (2004). Biological activities and distribution of plant saponins. Journal of Ethnopharmacology, 94, 219-243.

Taiz, L. \& Zeiger, E. (2013). Fisiologia vegetal (5 ${ }^{\text {a }}$ ed.). Porto Alegre: Artmed.

Vermes, I., Haanen, C., \& Reutelingsperger, C. (2000). Flow cytometry of apoptotic cell death. Journal of Immunological Methods, 243, 67-190.

Wedge, D. E., Galindo, J. C. G., \& Macías, F. A. (2000). Fungicidal activity of natural and synthetic sesquiterpene lactone analogs. Phytochemistry, 53, 747-757.

Zeng, R. S., Luo, S. M., \& Shi, Y. H. (2001). Physiological and biochemical mechanism of allelopathy of secalonic acid on higher plants. Agronomy Journal, 93, 72-79. 
